\title{
MALTOSE AS AN ENERGY SUBSTRATE DURING SURGERY: COMPARISON OF MALTOSE WITH GLUCOSE
}

\author{
Kazuya Aono, Nobuko Kawachino and KunihIKo SaTOH
}

\begin{abstract}
To evaluate the usefulness of maltose as an energy substrate to be administered during surgery, five per cent maltose in lactated Ringer's solution and five per cent glucose in lactated Ringer's solution were administered to 10 cases each, at a rate of $5 \mathrm{ml} \cdot \mathrm{kg}^{-1}$ hour $\left(0.25 \mathrm{~g} \cdot \mathrm{kg}^{-1}\right.$ hour as sugar) for two hours from the start of oral surgery, and their metabolic effects were compared.

The maltose group showed a smaller increase in blood sugar level than the glucose group immediately after the completion of infusion. The mean plasma concentration of maltose reached a maximum of $121.6 \mathrm{mg} / \mathrm{dl}$, and it remained at $12.3 \mathrm{mg} / \mathrm{dl}$ at four hours, indicating that the retention time of maltose in blood was longer than that of glucose. The mean recovery of sugar from four-hour urine samples was 3.26 per cent in the maltose group and 0.06 per cent in the glucose group respectively, showing greater urinary excretion by the maltose group.

Plasma insulin was elevated less after maltose than after glucose infusion. The elevation following maltose infusion was considered not to be due to the administration of maltose per se, but to glucose produced from the maltose in the body.

The anti-ketogenic effect of maltose was comparable to and tended to last longer than that of glucose.

From overall assessment it was concluded that maltose exerts essentially the same metabolic effects as glucose when used under these conditions.
\end{abstract}

Key Words: Metabolism, energy substrate, maltose, glucose.

THE PATIENT is often in a starved state when exposed to the stress caused by surgical operations or other therapy. The stress usually accelerates catabolic responses in the body. However, in such a state there is little sugar in the body usable as an energy source (mainly glycogen) and hence, once it is consumed, muscle protein begins to be converted to glucose by gluconeogenesis and fat tissues are converted to free fatty acids. As a consequence, these are used as a main energy source. The use of protein and fat wastes muscle tissue and induces increases in ketone body and free fatty acid concentrations. To prevent these phenomena, it is necessary to supply sugar as an energy source. Moffitt, et al. ${ }^{1}$ reported that glucose given during abdominal surgery increased the metabolism of glucose and decreased the utilization of fat.

On the other hand, Young and Weser, et al..$^{2,3}$ demonstrated that intravenous maltose is well

Kazuya Aono, M.D., Professor; Nobuko Kawachino, B.S., Kunihiko Satoh, D.D.S., Assistants; Department of Anesthesiology, Fukuoka Dental College, Fukuoka, 814-01 Japain.

Can. Anaesth. Soc. J., vol. 29, no. 3, May 1982 utilized in humans. Since then, maltose has been widely used in Japan. Subsequent studies have shown that maltose does not markedly increase blood sugar level and is less insulin-dependent than glucose. A 10 per cent solution of maltose has about the same osmotic pressure as that of plasma, half of that of glucose in the same concentration, which implies that at the same osmotic pressure maltose supplies twice as many calories as glucose. A considerable amount of sugar is excreted in the urine when maltose is infused at speeds of $0.5-1.0 \mathrm{~g} \cdot \mathrm{kg}^{-1} /$ hour. In general, tolerance to glucose decreases during surgery, which is called surgical diabetes. However, tolerance to maltose is reported to remain unchạnged during surgery. ${ }^{4}$

In order to evaluate the usefulness of maltose as a sugar source to be given during surgery, we infused maltose at a slower speed $\left(0.25 \mathrm{~g} \cdot \mathrm{kg}^{-1}\right)$ hour) than in previous tests, examined blood and urinary glucose and maltose concentrations, plasma insulin level, ketone bodies, free fatty acids, plasma osmotic pressure and urinary nitrogen, and compared the results obtained with 
those for glucose infused under the same conditions.

\section{Subjects AND MethodS}

Twenty patients, aged from 16 to 50 years, who were diagnosed free of metabolic disorders and scheduled to undergo oral surgery were divided into two groups of 10 each for administration of glucose (Group G) and maltose (Group M) (Table I). All patients gave their consent after being informed of the test procedures and blood samplings by the physician in charge.

Anaesthesia was condutt $d$ by the combination of nitrous oxide oxygen-methoxyflurane and modified neuroleptanaesthesia. At the beginning of operation infusion of either five per cent glucose in lactated Ringer's solution or five per cent maltose in lactated Ringer's solution was begun at the speed of $5 \mathrm{ml} \cdot \mathrm{kg}^{-1} /$ hour (or $0.25 \mathrm{~g} \cdot \mathrm{kg}^{-1}$ /hour as sugar) and continued for two hours. Before and after the glucose or maltose infusion, lactated Ringer's solution was given slowly. The blood was sampled before the anaesthetic induction, just before the start of operation and two, four and six hours after the start of operation for a total of five times. The urine was collected two and six hours after the beginning of operation. (Figure 1). Immediately after obtaining blood samples with heparinized syringes, $5 \mathrm{ml}$ of the blood was thoroughly mixed with the same volume of 10 per cent $(w / v)$ perchloric acid solution previously cooled with ice, and then centrifuged to obtain the supernate, which was then examined for ketone bodies. The remaining blood was cooled with ice and centrifuged to separate the plasma. The plasma was examined for substances other than ketone bodies.

The plasma and urine glucose levels were determined with hexokinase by the enzymatic method (Glucose HK test-Glucoquant ${ }^{\circledR}$, Böh-

TABLE I

SUBJECTS

\begin{tabular}{lcc}
\hline & Group G & Group M \\
\hline Age (years) & $37.1 \pm 4.2^{*}$ & $28.5 \pm 3.2^{*}$ \\
Sex male & 4 & 5 \\
female & 6 & 5 \\
Weight $(\mathrm{kg})$ & $53.6 \pm 2.4^{*}$ & $51.3 \pm 3.2^{*}$ \\
Height $(\mathrm{cm})$ & $157.0 \pm 1.9^{*}$ & $163.2 \pm 2.6^{*}$ \\
Sugar administered & glucose & maltose \\
Number & 10 & 10 \\
\hline
\end{tabular}

*Mean \pm standard error.
Group G; $5 \%$ glucose in L.R. . $-0.25 \mathrm{~g} / \mathrm{kg} / \mathrm{hr}$ Group $M ; 58$ maltose in L.R. ${ }^{-}$for 2 hours

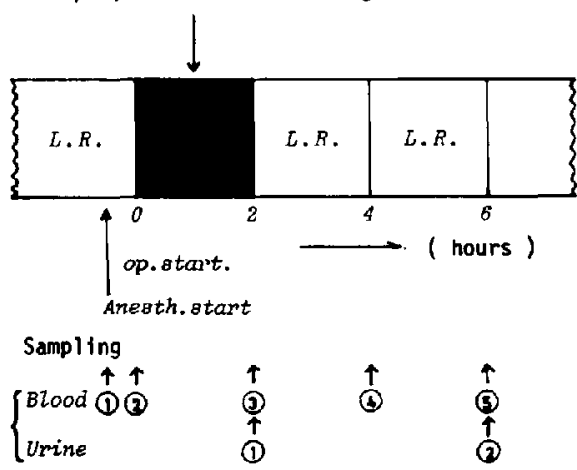

FIGURE 1 Experimental procedures.

ringer Mannheim), maltose by the maltaseglucose oxidase method, ${ }^{5}$ plasma insulin by radioimmunoassay, blood ketone bodies (betahydroxybutyrate and acetoacetate) by the enzymatic method, ${ }^{6}$ plasma free fatty acids by the modified Ui and Itaya method, ${ }^{7}$ urine nitrogen by Kjeldahl-Nessler method, plasma osmotic pressure by the freezing-point method, and plasma sodium and potassium by flamephotometry. Plasma inorganic phosphorus was measured by the Fiske-Subbarow method in three cases from each group. ${ }^{8}$

\section{RESULTS}

At the end of infusion, the mean value of plasma glucose rose from $80.0 \mathrm{mg} / \mathrm{dl}$ to 156.1 $\mathrm{mg} / \mathrm{dl}$ in Group $\mathrm{G}$, showing a significant increase of 95 per cent, and from $78.9 \mathrm{mg} / \mathrm{dl}$ to $103.9 \mathrm{mg} /$ dl in Group $M$, also showing a significant increase of 32 per cent. The highest glucose level at the end of infusion was significantly lower in Group $M$ than in Group $G$ (Figure 2). The plasma glucose concentrations in Groups $G$ and $\mathrm{M}$ declined almost to the previous levels two hours after the completion of infusion, though the latter still showed a higher level than the former.

The mean value of plasma maltose in Group $M$ was $121.6 \pm 7.0 \mathrm{mg} / \mathrm{dl}$ at the end of infusion, declined to $37.2 \pm 2.6 \mathrm{mg} / \mathrm{dl}$ at two hours, and decreased further to $12.3 \pm 1.7 \mathrm{mg} / \mathrm{dl}$ at four hours. So even after four hours, maltose persisted in the blood (Figure 3).

The recovery of glucose in the urine collected during the four hours after infusion was $15.7 \mathrm{mg}$ on the average in Group $\mathrm{G}(0.06$ per cent of the 
TABLE II

Urine Volume, Specific Gravity and Sugar Excretion in Each Group

\begin{tabular}{|c|c|c|c|c|c|c|}
\hline & $\begin{array}{c}\text { Urine } \\
\text { Volume } \\
(\mathrm{ml})\end{array}$ & $\begin{array}{l}\text { Specific } \\
\text { Gravity }\end{array}$ & $\begin{array}{c}\text { Dose Of } \\
\text { Sugar } \\
\text { (g) }\end{array}$ & $\begin{array}{l}\text { Sugar Excretion } \\
\text { (mg) }\end{array}$ & & $\begin{array}{l}\text { Rate Of } \\
\text { Excretion } \\
\text { (per cent) }\end{array}$ \\
\hline Group G & $\begin{array}{r}536.3 \\
\pm 67.6\end{array}$ & $\begin{array}{r}1.016 \\
\pm .002\end{array}$ & $\begin{array}{r}27.0 \\
\pm 1.1\end{array}$ & Glucose $15.7 \pm 6.6$ & & 0.06 \\
\hline Group M & $\begin{array}{r}782.7 \\
\pm 134.3\end{array}$ & $\begin{array}{r}1.016 \\
\pm .002\end{array}$ & $\begin{array}{l}25.3^{*} \\
\pm 1.7\end{array}$ & $\begin{array}{r}\text { Glucose } 205.7^{*} \\
\pm 44.8 \\
\\
\text { Maltose } 619.3^{*} \\
\pm 167.2\end{array}$ & $\begin{aligned} & 825.0^{*} \\
\pm & 168.7\end{aligned}$ & 3.26 \\
\hline
\end{tabular}

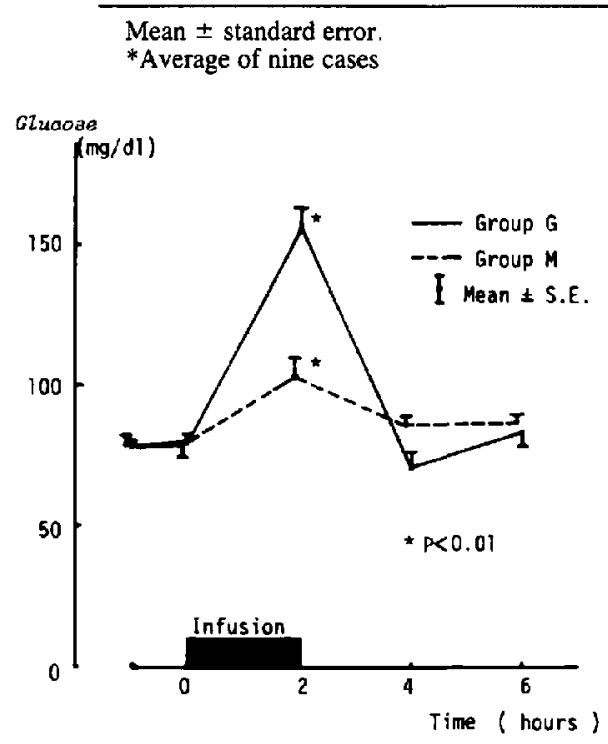

Figure 2 Changes in plasma glucose during and after infusion.

dose given) and $205.7 \mathrm{mg}$ on the average in Group $M(0.81$ per cent of the dose given). Maltose was also excreted in the urine in Group $\mathrm{M}$, at an average of $619.3 \mathrm{mg}$ (2.45 per cent of the dose given). In Group $M$, therefore, a total of $825.0 \mathrm{mg}$ ( 3.26 per cent of the given dose) was recovered from the urine during the four hour period (Table II, Figure 4). There was no correlation between the amounts of sugar infused and excreted. There were no significant differences in urine volume and specific gravity between the two groups. Urine output varied considerably among the patients (Table II).

The mean value of plasma insulin changed from $7.0 \mu \mathrm{U} / \mathrm{ml}$ before infusion to $37.7 \mu \mathrm{U} / \mathrm{ml}$ after infusion in Group $\mathrm{G}$ and from $8.6 \mu \mathrm{U} / \mathrm{ml}$ to $24.7 \mu \mathrm{U} / \mathrm{ml}$ in Group $M$, showing significant

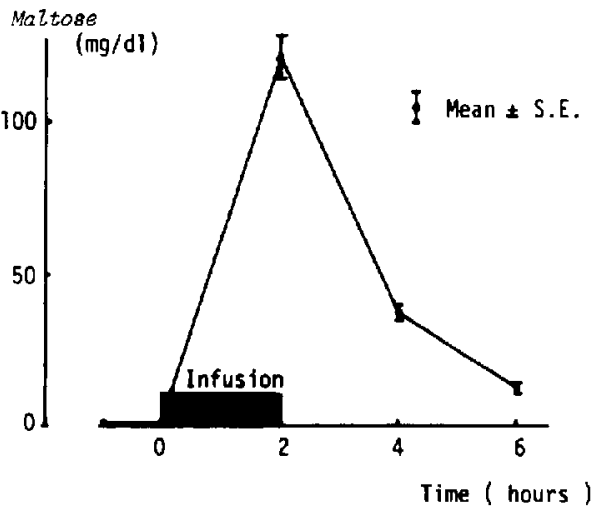

FIGURE 3 Changes in plasma maltose during and after infusion.

rises in both groups after infusion. It declined almost to the prior level in both groups two hours after the completion of infusion (Figure 5). The I/G ratio (the ratio of the insulin level to the glucose level and indicates the degree of insulin release due to glucose) at the maximum level was 0.242 in Group $\mathrm{G}$ and 0.238 in Group $\mathrm{M}$, showing no difference between the two groups (Table III).

The concentration of ketone bodies in the plasma was decreased in all patients at the end of infusion compared with values before infusion. Their mean values changed from $0.034 \mathrm{mM} / 1$ before infusion to $0.021 \mathrm{mM} / \mathrm{l}(61.8$ per cent) after infusion in Group $G$ and from $0.042 \mathrm{mM} / \mathrm{l}$ to $0.023 \mathrm{mM} / 1$ ( 54.8 per cent) in Group $M$ (Figure 6). At two hours after the completion of infusion, plasma ketone body levels rose to $0.044 \mathrm{mM} / 1$ in Group $\mathrm{G}$, showing a significant rise compared with the level at the end of infusion, and to $0.035 \mathrm{mM} / 1$ in Group $\mathrm{M}$, show- 
TABLE III

Insulin-Glucose (I/G) Ratio in Each Group

\begin{tabular}{llccccc}
\hline \hline & $\begin{array}{c}\text { Before } \\
\text { Anaesthesia }\end{array}$ & $\begin{array}{c}\text { Before } \\
\text { Infusion }\end{array}$ & $\begin{array}{c}\text { Immediately } \\
\text { After } \\
\text { Infusion }\end{array}$ & $\begin{array}{c}\text { Two Hours } \\
\text { After } \\
\text { Infusion }\end{array}$ & $\begin{array}{c}\text { Four Hours } \\
\text { After } \\
\text { Infusion }\end{array}$ \\
\hline Group G & Glucose & $77.8 \pm 2.6$ & $80.0 \pm 2.9$ & $156.1 \pm 6.8$ & $71.9 \pm 4.9$ & $84.2 \pm 5.7$ \\
& Insulin & $6.3 \pm 1.2$ & $7.0 \pm 1.0$ & $37.7 \pm 5.5$ & $12.7 \pm 4.4$ & $8.1 \pm 2.0$ \\
& IGG ratio & 0.081 & 0.088 & 0.242 & 0.177 & 0.096 \\
Group M & Glucose & $79.0 \pm 3.4$ & $73.9 \pm 4.2$ & $103.9 \pm 6.2$ & $86.0 \pm 3.5$ & $86.9 \pm 3.2$ \\
& Insulin & $10.9 \pm 2.6$ & $8.6 \pm 1.3$ & $24.7 \pm 7.0$ & $11.7 \pm 1.9$ & $10.5 \pm 2.4$ \\
& I/G ratio & 0.138 & 0.109 & 0.238 & 0.136 & 0.121 \\
\hline
\end{tabular}

Mean \pm standard error
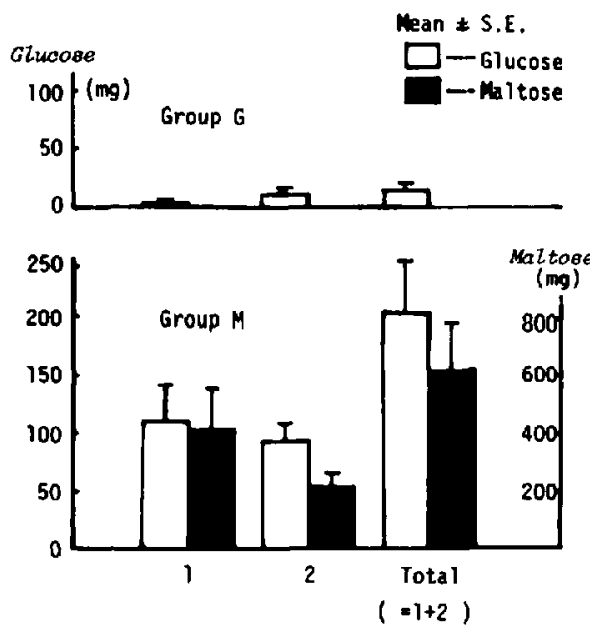

FIGURE 4 Urinary excretion of glucose and maltose

ing no significant increase. Two hours later (four hours after the completion of infusion), the mean concentrations of ketone bodies in plasma were $0.135 \mathrm{mM} / \mathrm{l}$ in Group $\mathrm{G}$ and $0.099 \mathrm{mM} / 1$ in Group M. Group $M$ showed a lower value than Group $\mathrm{G}$, but the difference was not statistically significant. Compared with their respective prior values, these mean concentrations at four hours were significantly higher in both groups (Figure 6).

The change in plasma non-esterified fatty acid (NEFA) concentration was found to be generally similar to plasma ketone body concentration (Figure 7). Both Groups, G and M, showed tendencies for decrease in plasma NEFA at the end of infusion, though the decreases were not significant. NEFA level continued to increase in both groups up to four hours after infusion. There was no significant difference in the NEFA levels of the two groups.

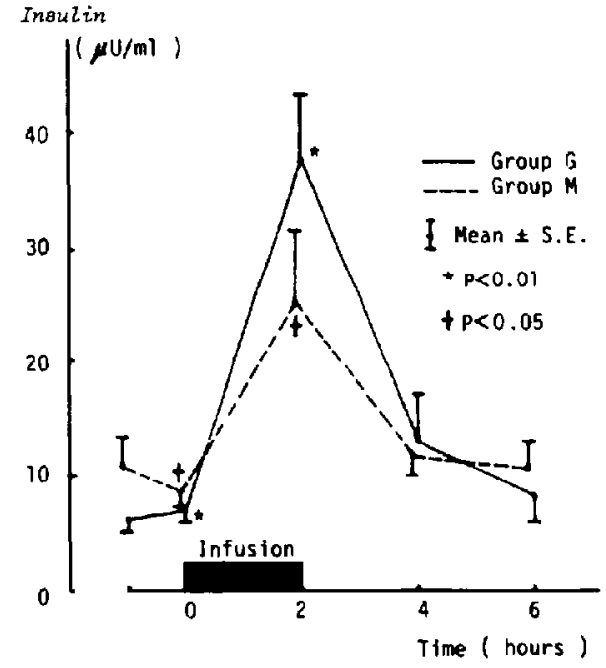

Figure 5 Changes in plasma insulin during and after infusion.

The urinary excretion of nitrogen amounted to $3.52 \pm 0.33 \mathrm{~g}$ (mean \pm S.E.) in Group $\mathrm{G}$ and $3.92 \pm 0.36 \mathrm{~g}$ in Group $M$ during the four hours after infusion (Figure 8). There was no significant difference in urinary nitrogen excretion between the two groups.

Neither group revealed any significant changes in plasma electrolytes (sodium and potassium), osmotic pressure and inorganic phosphorus before and after infusion. They varied within the normal range.

\section{Discussion}

In order to evaluate the usefulness of maltose as a sugar source to be supplied during surgery, maltose and glucose were infused during oral surgery and their effects were compared by measuring metabolites in the blood and urine. 


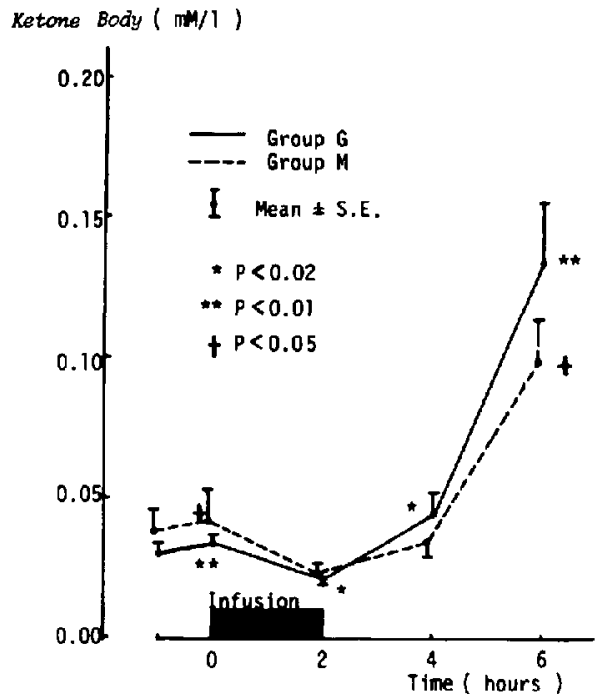

FIGURE 6 Changes in blood ketone body during and after infusion.

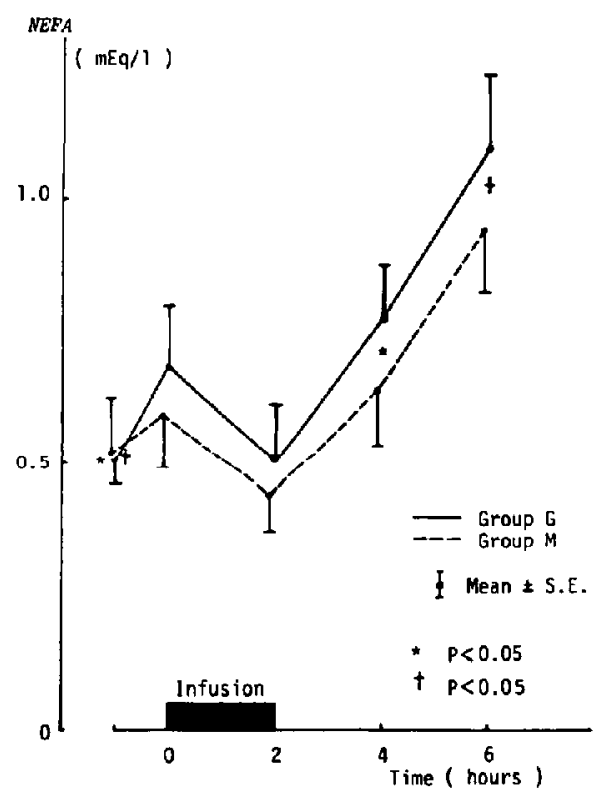

FIgURE 7 Changes in plasma non esterified fatty acid (NEFA) during and after infusion.

Plasma glucose levels increased in both groups immediately after the end of infusion. The increase was greater in Group $G$ than in Group M. Maltase, which decomposes maltose, is not present in the human blood, and hence the

\section{Nitrogen}
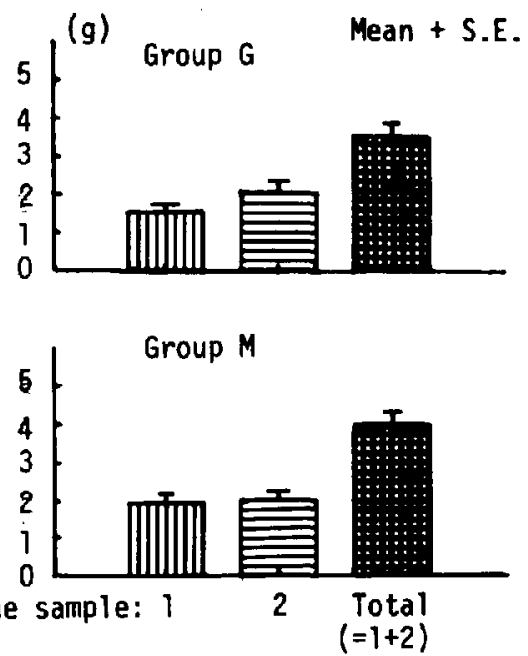

FIGURE 8 Urinary excretion of nitrogen.

infused maltose will be taken into the cells where it is converted to glucose by maltase, so that the glucose produced may escape from cells into extracellular fluid. This seemed to account for the moderate increase in the plasma glucose level in Group $\mathbf{M}$ at the end of infusion.

The mean concentration of plasma glucose decreased to the prior level in Group $\mathrm{G}$ two hours after infusion (Figure 2), whereas in Group $M$ plasma maltose increased sharply to $121.6 \mathrm{mg} / \mathrm{dl}$ immediately after the end of infusion and then decreased to $37.2 \mathrm{mg} / \mathrm{dl}$ after two hours and to $12.3 \mathrm{mg} / \mathrm{dl}$ after another two hours. The results suggest that the clearance of maltose from the blood is slower than that of glucose. Young and Weser et al ${ }^{9}$ have already pointed out the fact that maltose is metabolized more slowly than glucose.

The urinary excretion of glucose was practically nil in Group $G$, while it amounted to an average of $205.7 \mathrm{mg}$ ( 0.81 per cent of the given dose) in group $M$ (Table II). Incidentally, the increase in plasma glucose level following maltose infusion was about one third of that following glucose infusion, and the glucose level of Group $\mathrm{M}$ was below the renal glucose clearance threshold (generally, $180 \mathrm{mg} / \mathrm{dl}$ as blood sugar). Despite these facts, Group $M$ excreted more glucose in the urine than Group $G$. The reason for this is thought to be that maltase activity is high in the kidney ${ }^{10}$ where maltose is decomposed to glucose by maltase and some of the 
glucose produced is not reabsorbed, but excreted directly in the urine. On the other hand, the reabsorbed glucose is thought to increase blood sugar level. This assumption is supported by the findings that blood sugar levels increased more markedly in the renal venous blood than in the renal arterial blood when maltose was given to rabbits. ${ }^{11}$

In Group $M$ the highest plasma maltose level was only $121.6 \pm 7.0 \mathrm{mg} / \mathrm{dl}$, but the average urinary excretion of maltose was $619.3 \mathrm{mg}(2.45$ per cent of the given dose) (Table II). The renal maltose clearance threshold is estimated to be $80-100 \mathrm{mg} / \mathrm{dl}$ in blood concentration. The clear ance of maltose in the present study seemed to be consistent with the estimated value.

When given intravenously to heal thy subjects, maltose is reported to be excreted less as sugar in the urine than sorbitol and xylitol, but more than glucose. Since maltose is metabolized more slowly than glucose, ${ }^{9}$ it is necessary to slow down the speed of infusion to reduce the urinary excretion of sugar after maltose administration. In fact, a two hour infusion of maltose at a speed of about $0.5 \mathrm{~g} \cdot \mathrm{kg}^{-1} /$ hour was reported to result in a 10.5 per cent recovery in the one hour urine sample ${ }^{12}$ and a 27 per cent recovery in the two hour urine sample; ${ }^{13}$ but in our present study maltose given at the speed of $0.25 \mathrm{~g} \cdot \mathrm{kg}^{-1} /$ hour for two hours resulted in only a 3.26 per cent recovery on the average during the four hours after infusion (Table II).

Plasma insulin was elevated significantly in both Groups at the end of infusion compared with the prior levels. The $I / G$ ratio at the maximum insulin level following the completion of infusion (the ratio of plasma insulin to blood sugar) was 0.242 in Group G and 0.238 in Group $M$, showing almost no difference between the groups. This seems to suggest that the rise in plasma insulin level observed in Group $M$ was due to the glucose produced from the infused maltose and that maltose per se had no stimulating effect on insulin secretion, especially early phase insulin release. This finding is in agreement with the results obtained in the experiment with perfused rat pancreas ${ }^{14}$ as well as the tolerance test in man. ${ }^{4}$

Both groups showed decreases in blood ketone bodies to 61.8 per cent and 54.8 per cent of the prior levels at the end of infusion. At two hours after infusion, however, ketone body levels rose slightly in both groups, returning to values almost the same as those before the sugar infusion. The results suggest that the maltose given during the operation exerted substantially the same anti-ketogenic effect as the glucose. The blood ketone body level at two hours after infusion was significantly high compared with that at the end of infusion in Group G, but not in Group M. At four hours mean ketone body levels were lower in Group M than in Group G (Figure 6). These findings indicate that infused maltose has a longer anti-ketogenic effect than glucose.

The plasma level of non-esterified fatty acids had a tendency to decrease, though not significantly, in both Groups $G$ and $M$ at the end of infusion. The changes in non-esterified fatty acid level appeared to be of the same degree in both groups; that is NEFA continued to increase in both groups up to four hours after infusion and there was no significant difference between the two groups. NEFA, however, varied greatly among the patients as it changes sharply every moment (Figure 7).

The mean urinary excretion of nitrogen measured for the four hours after infusion was not found to be significantly different between the two groups. This seems to indicate that the protein sparing effect of maltose is comparable to that of glucose.

The osmotic pressure of plasma was virtually unaltered in either group. The two infusions had different osmotic pressures (about $551 \mathrm{mOsm} / 1$ for five per cent glucose in lactated Ringer's solution and about $412 \mathrm{mOsm} / \mathrm{l}$ for five per cent maltose in lactated Ringer's solution). However since they were infused relatively slowly, it is thought that both carbohydrates were almost completely metabolized and hence the osmotic pressure of plasma was not affected by their infusion.

In short the following conclusion can be drawn from the comparison of maltose with glucose infused during oral surgery. The rise in blood sugar level is smaller after maltose infusion than after glucose infusion, but maltose itself persists in the blood for a relatively long period of time. Maltose infusion induces more urinary excretion of sugar than does glucose infusion. Plasma insulin is elevated less by maltose than by glucose, and the elevation is not due to maltose per se, but is supposed to be due to glucose produced from the administered maltose. The anti-ketogenic effect of maltose tends to last longer than that of glucose.

In the present trial infusion was made at a relatively slow speed $\left(5 \mathrm{ml} \cdot \mathrm{kg}^{-1} /\right.$ hour, or 0.25 $\mathrm{g} \cdot \mathrm{kg}^{-1}$ /hour as sugar). In general, oral surgery causes a relatively small loss of extracellular 
fluid and stress is also mild compared with intra-abdominal operations. The speed of infusion employed in the present study caused no remarkable changes in blood pressure or heart rate, nor did it cause any remarkable decrease in urine output. In an operation that is anticipated to cause a large loss of extracellular fluid, however, lactated Ringer's solution should be given separately at a speed adjusted to replenish the lost extracellular fluid while carbohydrate infusion be maintained at a constant speed.

\section{REFERENCES}

1. Moffit, E. A., SCHNelle, N., Rodriguez, R. LEE, R.A. \& JUDD, E.S. Effects of intravenously administered solutions on electrolytes and energy substrates during surgery. Can. Anaesth. Soc. J. 2I: 285 (1974).

2. Weser, E. \& Sleisenger, M.H. Metabolism of circulating disaccharides in man and the rat. J. Clin. Invest. 46: 499 (1967)

3. YouNG, S.J.M. \& WESER, E. The metabolism of circulating maltose in man. J. Clin. Invest. 50: $986(1971)$.

4. Aono, K., Harano, K. \& Hirokata, Y. Changes of carbohydrate tolerance during surgery. Comparison between glucose and maltose. Japan. J. Anesthesiol. 23: 797 (1974).

5. Nakagawa, J., TSUtsumi, K, Uenoyama, T. \& Fujiwara, H. Determination of maltose, disaccharide, by maltase-glucose oxidase method. Clin. Report 6: 72 (1972)

6. Williamson, D.H., Mellanby, J. \& Krebs, H.A. Enzymatic determination of $D(-)-\beta$ hydroxybutyric acid and acetoacetic acid in blood. Biochem. J. 82: 90 (1962).

7. ITAYA, K. \& UI, M. Colorimetric determination of free fatty acids in biological fuids. J. Lipid Res. 6: 16 (1965).

8. Fiske, C.H. \& Subbarow, Y. The colorimetric determination of phosphorus. J. Biol. Chem. 6 : 375 (1925).

9. Young, E.A. \& WeSER, E. The metabolism of maltose after intravenous injection in normal and diabetic subjects. J. Clin. Endocrinol. Metab. 38: 181 (1974).

10. Fujil, S., OKuda, H. \& Matsuda, I. Studies on maltose. I. Metabolism of maltose in animals. The Saishin-Igaku, 27: 1584 (1972).

11. Ohneda, A., Matsuda, K. \& Tsutsumi, K. Maltose metabolism in the kidney of rabbits. J. Japan Diab. Soc. 16: 135 (1973).

12. Yamada, M., Ito, K., MOMOSE, T. \& ISHII, S. Clinical studies on the lactated Ringer solution containing 5 per cent maltose (an assumed title). J. New Rem. Clin., 26: 47 (1977).

13. Kitamura, Y., Kitamura, E., Konishi, A.\& FujIMORI, M. Comparative study on the lactated Ringer solutions containing sugars (an assumed title). Clin. Med., 19: 85 (1977).

14. Toyota, T., ANDo, Y., Nishimura, H. \& HiRaTa, Y. Effects of Maltose on insulin secretion in perfused rat pancreas. Tohoku J. Exp. Med. 104: 305 (1971).

\section{RÉSumé}

Dans le but d'évaluer le maltose comme substrat énergétique per-opérataire, on a administré à deux groupes de 10 patients soit du maltose cinq, pour cent dans une solution de Ringer au lactate, soit du glucose cinq pour cent dans la même solution à la vitesse de $5 \mathrm{ml} \cdot \mathrm{kg}^{-1}$ à l'heure, pendant les deux premières heures d'une intervention en chinurgie buccale.

Immédiatement après la perfusion, le groupe qui a reçu le maltose a montré une augmentation plus faible du taux de glycémie que le groupe qui a reçu la solution glucosée. La concentration mayenne de maltose plasmatique a atteint un maximum de $121.6 \mathrm{mg} / \mathrm{dl}$ pour diminuer à $12.3 \mathrm{mg} / \mathrm{dl}$ après quatre heures, ce qui démontre que la durée de rétention du maltose dans le sang est plus longue que celle du glucose. La récupération moyenne du sucre dans les urines de vingt quatre heures a été de 3.26 pour cent pour le groupe maltose et de 0.06 pour cent pour le groupe glucose, ce qui permet de conclure que dans le groupe maltose l'excrétion urinaire est plus élevée.

L'insuline plasmatique a moins augmenté après la perfusion de maltose qu'après la perfusion de glucose. Cette ếlévation de l'insuline après la perfusion de maltose ne semble pas causée directement par le maltose, mais plutôt par la transfornation de maltose en glucose. L'effet anti-cétonique du maltose est comparable à celui du glucose mais se prolonge plus longtemps.

Cette étude permet de conclure qu'en général le maltose produit essentiellement les mêmes effets métaboliques que le glucose dans les conditions de l'expérience. 